\title{
Phosphate solubilizing yeast isolated and characterized from teff rhizosphere soil collected from gojam; Ethiopia
}

\begin{abstract}
Phosphorous is an essential macronutrient for plant growth and development. About 95$99 \%$ present in soil insoluble form. Phosphate solubilizing microorganisms can increase soil phosphate solubility and availability. This study was aimed to identify and evaluate phosphate solubilizing yeast from Teff rhizosphere soil. Yeasts were identified using Biolog Micro station identification system. Yeast isolates were screened and transferred to biolog universal yeast agar media. Pure yeast cells were suspended in sterile water at $49 \pm 2$ turbidity measured by biolog turbidimeter. $100 \mu$ - $\mathrm{L}$ transferred from each suspension into 96 wells of the biology yeast micro Plate tagged with different carbon source and incubated at $26^{\circ} \mathrm{C}$ for 24 to $72 \mathrm{~h}$ and read by micro station at a single wavelength of $590 \mathrm{~nm}$, results were recorded and processed for identification by micro $\log 3$ software ver. 4.20 .05 . Above 0.5 similarities index value is acceptable species identification. Therefore biolog microstations identify nine yeast species with full species identity. The identified yeasts were tested for phosphate solubilization by the Pikovskaya's agar (PVK) selective media. Nine yeast species were positive in phosphate solubilizing ability. Phichia norvegensis, Cryptococcus albidus var aerius, Candida etchellsii, Cryptococcus albidus var albidus, Rhodotrula aurantiacaA, Rhodotorula aurantiaca B, Cryptococcus luteolus, Cryptococcus albidus var diffluens, Cryptococcus terreus A. At 15days incubation their phosphate solubilizing index (PSI) ranges 1.72-3.35. Phichia norvegensis and Cryptococcus albidus var aerius were superior in phosphate solubilization 3.35 and 3.2 SPI respectively. Therefore these species can be candidated and exploited after further evaluation as bio fertilizers for teff productivity.
\end{abstract}

Keywords: biolog, microorganisms, microstation, phosphorus, rhizospher, soil, solubilization, teff
Volume 5 Issue I - 2017

Birhanu Gizaw, Zerihun Tsegay, Genene Tefera, Endegena Aynalem, Misganaw wassie, Endeshaw Abatneh, Getasew Amsalu Microbial Biodiversity Directorate, Ethiopian Biodiversity Institute, Ethiopia

Correspondence: Birhanu Gizaw, Microbial Biodiversity Directorate, Ethiopian Biodiversity Institute, P.O. box 30726, Addis Ababa, Ethiopia, Tel +25 I91 186256I or 0933578070 , Email gbirhanu@ibc.gov.et

Received: June 05, 2017| Published: June 30, 2017

\section{Introduction}

Improving soil fertility is one of the most common practices in agricultural productivity for all crops. Teff [Eragrostistef (Zucc.) Trotter] is the major indigenous cereal crop of Ethiopia, where it was originated and diversified. It is a highly demanded and a staple food grain for $60-65 \%$ of the Ethiopian people. In a country of over 80 million people, teff accounts for about $15 \%$ of all calories consumed in Ethiopia. ${ }^{1}$ More than $70-75 \%$ of Ethiopian highland soils are characterized by phosphorus deficiency. ${ }^{2}$ The deficiency is very severe in the acidic soils of the southern, southwestern and western regions. Areas $\mathrm{Al} 3+$ and $\mathrm{Fe} 3+$ high are totally incriminated with phosphorus fixation. ${ }^{3}$ Around $70 \%$ of Ethiopian vertisol have available phosphorus below $5 \mathrm{ppm}$, which is very low for supporting good teff growth and phosphorus fixation in vertisols is related more to calcium. ${ }^{4}$

Phosphorus is one of the major nutrients second to nitrogen required by plants for growth and productivity. It contributes remarkably to photosynthesis, sugar production, nucleic acid synthesis, and promotes N2 fixation in legume and energy production. ${ }^{5}$ It also increases the strength of cereal straw, promotes flower formation, fruit production, stimulates root development and also essential for seed formation, stalk and stem strength, maturity and production crop quality and resistance to plant diseases. ${ }^{6} \mathrm{~A}$ greater part of soil organic and inorganic phosphorus, approximately $95-99 \%$ is present in the form of insoluble phosphates that is bound by $\mathrm{Al}$ or Fe in acid soils, or $\mathrm{Ca}$ and $\mathrm{Mg}$ in alkaline soils which cannot be utilized by the plants easily. ${ }^{7,8}$

Declining soil fertility as a result of continuous cropping without replenishing soil nutrients continues application of phosphate fertilizer and soil erosions is the major factors that reducing production and productivity of the teff crop in Ethiopia. Higher grain yield of teff was recorded by applying inorganic fertilizers. ${ }^{9}$ However chemical fertilizers are neither easily available nor affordable for the majority of poor Ethiopian farmers and not environmentally friendly and also the recovery rate of Phosphate fertilizer by plants is only about 10 to $30 \%$. The remaining 70 to $90 \%$ is accumulated in soil or in the form of immobile that is bound by $\mathrm{Al}$ or $\mathrm{Fe}$ in acid soils, or $\mathrm{Ca}$ and $\mathrm{Mg}$ in alkaline soils. ${ }^{78}$ Such economic considerations and phosphate existence in compound form necessitate for an alternative less expensive and environmentally friendly bio fertilizer improving yield and quality of teff grain. In Ethiopia, only few studies on teff root-associated microorganisms have been undertaken. The effect of phosphate solubilizing some fungus on growth and yield of teff was studied by Asfaw. ${ }^{10}$ Inoculation of teff by vascular arbuscular mycorrhazal (VAM) and plant growth promoting rhizobacteria (PGPR) give good result on teff productivity. So previous research works tell us using bio fertilizer are better indicative to improve teff productivity to a significant level. However there are some trials on rhizobacteria and vascular arbscular mycorrhazal using as bio fertilizer, phosphate solubilizing yeast were not studied very well. 
Phosphate solubilizing microorganisms can play an important role in dissolving both of fertilizer phosphorus and bound phosphorus in the soil that is environmentally friendly and sustainable. ${ }^{11}$

Several groups of microorganism including fungi, bacteria and actinomycetes are known as efficient fixed $\mathrm{P}$ solubilizers. ${ }^{12}$ In last few decades a large array of rhizosphere bacteria and fungi including species of Azotobacter chroococcum, Bacillus subtilis, Bacillus cereus, Bacillus megaterium, Arthro bacterilicis, Escherichia coli, Pantoea agglomerans, Pseudomonas putida, Pseudomonas aeruginosa, Entero bacteraerogenes, Microbacterium laevaniformans, and Micrococcus luteus have been identified as P-fertilizers. ${ }^{13}$

Many fungal species can solubilize rock phosphate, aluminium phosphate and tricalcium phosphate, such as Aspergillus niger, Aspergillus tubingensis, Aspergillus fumigatus, Aspergillus terreus, Aspergillus awamor, Penicillium italicum, Penicillium radicum, Penicillium rugulosum, Fusarium oxysporum, Curvularialunata, Humicola sp., Sclerotiumrolfsii, Pythium sp., Aerothecium sp., Phoma sp., Cladosporiumsp, Rhizoctonia sp., Rhizoctoniasolani, Cunninghamella spp., Rhodotorula sp., Candida sp., Schwanniomyces occidentalis, Oideodendron sp., Pseudonymnoascus sp. Candida tropicalis, Geotrichum vcandidum, Geotrichum vcapitatum, Rhodotorula minuta and Rhodotorula rubra. Saccharomyces, Hansenula, Klockera, Rhodotorula and Debaryomycesspp.,. ${ }^{14-20}$ This study was aimed to isolate, identify and evaluating of phosphate solubilizing yeast from teff rhizosphere soil collected from Gojam farm land and selecting superior solubilizing yeast that will be candidated for bio fertilizer after further evaluation for teff crop productivity.

\section{Materials and methods}

\section{Study area}

The study was conducted in east and west Gojam in selected districts, particularly in Bichena, Bahirdar zuria, Huletejunaesae, Denbecha, Enarge enawga, Enemay, Dejenin Amhara regional state. East Gojam Zone is bordered on the south by the Oromia Region, on the west by , on the north by south Gondar, and on the east by south Wollo; the bend of the Abay River defines the Zone's northern, eastern and southern boundaries. $10^{\circ} 31^{\prime} 44.7^{\prime \prime} \mathrm{N} \& 37^{\circ} 51^{\prime} 10.2^{\prime \prime} \mathrm{E}$. West Gojjam (Mirab Gojjam) is one of the Zone in the Amhara Region of Ethiopia. West Gojjam is borded by North Gondar, on the north by Lake Tana, and the Abay River which separates it from the South Gondar, and on the east by east Gojjam. Coordinates: Latitude: 10.97379North, Longitude: 37.46814East.Gojam at Average altitude, 1788m.a.s.l. (Figure 1).
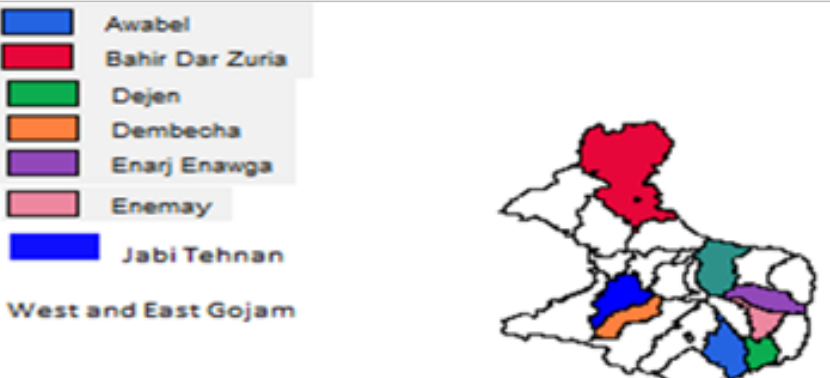

Figure I Map of study area.

\section{Sample collection}

Seventy five teff farmland sites were selected based on five teff varieties, two soil types and 200m difference within1400-1900m.a.s.1 altitude in the study area. Seventy five rhizosphere soils were collected through drillings at 5,10 , and $15 \mathrm{~cm}$ depth. Approximately $15 \mathrm{~g}$ of soil were taken from each depth of sampling point and a total of $45 \mathrm{~g}$ composite soil per sampling farmland were stored in sterile sample tube and icebox during November 7-17/2016 Figure 2 and transported microbial directorate laboratory in Ethiopian biodiversity institute to Addis Ababa and kept in $+4^{\circ} \mathrm{C}$ until processed.
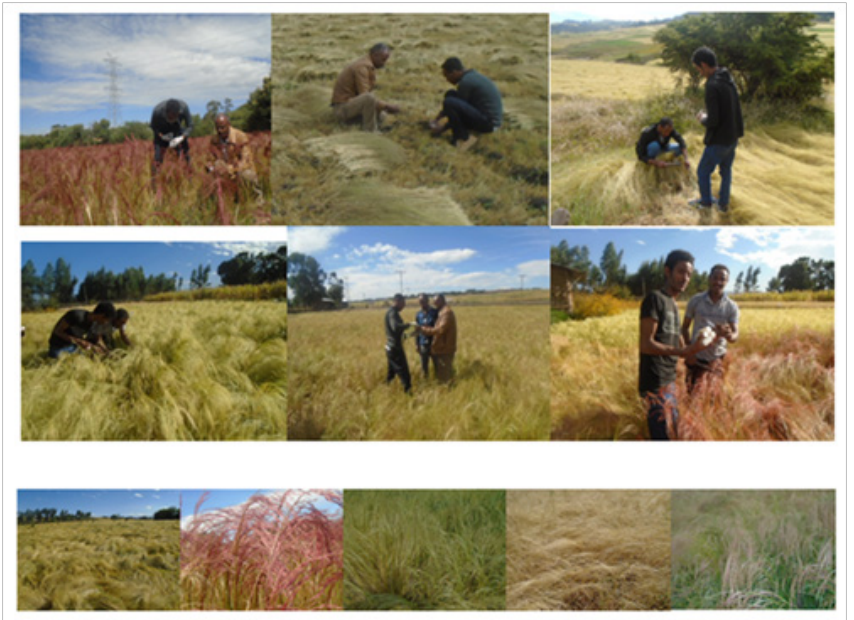

Figure 2 Activites during teff rhizosher soil collection and teff varieties.

\section{Screening and isolation of yeast from teff rhizosphere soil}

One gram of soil from each sample was serially diluted up to 10 $6 \mathrm{~mL}$ in distilled water. About $0.1 \mathrm{~mL}$ inoculum sample was transferred to yeast extract peptone dextrose agar media (YPDA) by cotton swab and streaked using nichrom loop. Primary cultures were incubated for $26^{\circ} \mathrm{C}$ in digital incubator for $48 \mathrm{~h}$. Isolates were subculture twice until pure colony obtained for morphological identification. A single yeast colony was streaked to Biolog universal yeast agar (BUY agar plate, $(60 \mathrm{~g} / 1 \mathrm{~L})$ and incubated for $48 \mathrm{~h}$ at $26^{\circ} \mathrm{C}$ for yeast (YT) Microplate) inoculum preparation. The yeasts were identified according to the Biolog micro station reading procedure (Biolog, 1993).

\section{Identification of colonial morphology}

The colony morphology of the isolated yeast were examined after grown on yeast extract peptone dextrose agar media and biolog universal yeast agar media at $26^{\circ} \mathrm{C}$ for $48 \mathrm{~h}$ and its colony morphology, form, size, elevation, margin/edge, colony color were observed using hand lens and recorded.

\section{Identification of yeast from teffrhizosphere soil using Biolog Microstation}

Pure yeast isolates were transferred to biolog universal yeast agar media and incubated at $26^{\circ} \mathrm{C}$ for $48 \mathrm{~h}$. Pure colony of yeast suspension were prepared in $9 \mathrm{~mL}$ sterile distilled water and adjusted to $47 \pm 2 \mathrm{~T}$ using biolog turbidiameter. $100 \mu-\mathrm{L}$ of inoculum was dispensed using digital pipettor to each of 96wells of yeast micropate (YT) and incubated at $26^{\circ} \mathrm{C} 24-72 \mathrm{~h}$. The YT micro plate is tagged with 96 carbon source. An isolate ability to metabolize each carbon source is measured in the presence or absence of purple hue in the wells. Tetrazolium violet a redox dye forms a purple color when oxidized by cellular respiration of microorganisms. The YT micro plate measures both metabolic reactions as well as turbidity growth to produce identifications. YT micro plate was read by the micro station reader at $24 \mathrm{~h}, 48 \mathrm{~h}$, and $72 \mathrm{~h}$ at a single wavelength of $590 \mathrm{~nm}$. The biolog 
software micro $\log 3$ ver. 4.20 .05 compared the results obtained with the test strain to the database and provided identification based on distance value of match and separation score produces similarity index value and probability for species identification. Above 0.5 similarities index value result is acceptable species identification. ${ }^{21}$

\section{Identification ofphosphate solubilizing microorganisms}

Yeast identified by biolog micro station was tested for their phosphate solubilizing ability. Pure yeast colony was collected using a needle nose and spot at 4 quadrants on sterile solid Pikovskaya media (2.5g Ca3(PO4), 0.5g $\left(\mathrm{NH}_{4}\right)_{2} \mathrm{SO}_{4}, 0.2 \mathrm{NaCl}, 0.1 \mathrm{~g} \mathrm{MgSO}_{4} .7 \mathrm{H}_{2} \mathrm{O}, 0.2 \mathrm{~g}$ $\mathrm{KCl}, 10 \mathrm{~g}$ glucose, $0.5 \mathrm{~g}$ of yeast extract, $20 \mathrm{~g}$ agar, $0.0001 \mathrm{~g} \mathrm{MnSO}_{4}$, $0.0001 \mathrm{~g} \mathrm{FeSO}_{4}, 1000 \mathrm{~mL}$ distilled water $)^{22} \mathrm{Ca}_{3}\left(\mathrm{PO}_{4}\right)_{2}$ was used as a source of phosphate. Observations were made until the formation of a clear zone around the colonies of yeast that indicated the occurrence of phosphate dissolution. At 5days intervals solubilization index (SI) was measured using following formula. ${ }^{23}$ Yeast that formed the fastest

Table I Colony morphology for phosphate solubilizing yeast clear areas with the greatest diameter indicates the most superior phosphate solubilizing yeast.

$$
\mathrm{SI}=\frac{\text { colony diameter }+ \text { halozone diameter }}{\text { Colony diameter }}
$$

\section{Statistical analysis}

The data analysis involved various descriptive statistics such as means and percentages frequency. STATA ver.13 was used for phosphate solubilization index data analysis.

\section{Results}

\section{Colonial morphology}

The phosphate solubilizing yeast isolates were identified based on their colony morphology depending on its pigmentation, shape, size, texture, elevation and margin. The following table summarizes the

\begin{tabular}{|c|c|c|c|c|c|c|c|}
\hline \multicolumn{2}{|c|}{ P-solubilizing fungi } & \multirow{2}{*}{$\begin{array}{l}\text { Shape } \\
\text { Irregular }\end{array}$} & \multirow{2}{*}{$\begin{array}{l}\text { Elevation } \\
\text { Flat }\end{array}$} & \multirow{2}{*}{$\begin{array}{l}\text { Size } \\
\text { Large }\end{array}$} & \multirow{2}{*}{$\begin{array}{l}\text { Margin } \\
\text { Lobate }\end{array}$} & \multirow{2}{*}{$\begin{array}{l}\text { Surface texture } \\
\text { Concentric }\end{array}$} & \multirow{2}{*}{$\begin{array}{l}\text { Color } \\
\text { Yellow }\end{array}$} \\
\hline I & Cryptococcus albidus var aerius & & & & & & \\
\hline 2 & Cryptococcusterreus A & Irregular & Flat & Large & Undulate & Smooth & White \\
\hline 3 & Cryptococcus albidus var albidus & Entire & Pulvinate & Large & Entire & Radiate & White yellow \\
\hline 4 & Rhodotorula aurantiaca $B$ & Irregular & Raised & Large & Undulate & Concentric & White \\
\hline 5 & Phichianorvegensis & Circular & Flat & Large & Entire & Concentric & White yellow \\
\hline 6 & Rhodotorula aurantiaca A & Rhound & Flat & Large & Undulate & Radiate & White brown \\
\hline 7 & Cryptococcus luteolus & Circular & Flat & Large & Erose & Concentric & Yellow white \\
\hline 8 & Candida etchellsii & Circular & Flat & Medium & Entire & Concentric & Yellow white \\
\hline 9 & Cryptococcus albidus vardiffluens & Entire & Flat & Large & Erose & Concentric & Yellow white \\
\hline
\end{tabular}
result (Table 1).

Identification of yeast species using biolog micro station

A total of 96yeast colonies were grown on yeast extract potato dextrose agar and counted. Pure colonies having similar morphology were clustered together in order to detect the percentage frequencies of the yeast. Representative yeast colony transferred into YT micro plate and read by biology microstion at 24,48 and $72 \mathrm{~h}$ incubation.
The result revealed that nine yeast $\geq 0.5$ similarity index values were identified. These are Phichia norvegensis, Cryptococcus albidus var aerius, Candida etchellsii, Cryptococcus albidus var albidus, Rhodotrula aurantiacaA, Rhodotorula aurantiaca B, Cryptococcus luteolus, Cryptococcus albidus var diffluens, Cryptococcus terreus and three yeast isolates has no species identification result. In this study Cryptococcus were the dominant species in percentage frequency (Table 2).

\begin{tabular}{|c|c|c|c|c|c|c|}
\hline \multicolumn{2}{|c|}{ Fungus species } & \multirow{2}{*}{$\begin{array}{l}\text { Probability } \\
100\end{array}$} & \multirow{2}{*}{$\begin{array}{l}\text { Similarity } \\
0.584\end{array}$} & \multirow{2}{*}{$\begin{array}{l}\text { Distance } \\
6.48\end{array}$} & \multirow{2}{*}{$\begin{array}{l}\text { Status } \\
\text { Identified }\end{array}$} & \multirow{2}{*}{$\begin{array}{l}\text { Yeast isolated from gojam specific districts } \\
\text { Bichena, Gotera Kebele }\end{array}$} \\
\hline I & Rhodotorula aurantiaca A & & & & & \\
\hline 2 & Candida etchellsii & 78 & 0.658 & 2.34 & Identified & Awabel, Enebi chifri \\
\hline 3 & Cryptococcus luteolus & - & 0.659 & 3.19 & Identified & Dejen Zemetin Kebele \\
\hline 4 & Cryptococcus albidus var aerius & 100 & 0.542 & 7.22 & Identified & Hulet eju enese, Debre Gubae Kebele \\
\hline 5 & Cryptococcus terreus A & 99 & 0.605 & 6.03 & Identified & Hulet eju enese, Debre Gubae Kebele \\
\hline 6 & Cryptococcus albidus var albidus & 93 & 0.598 & 5.49 & Identified & Jehabitenan, Jiga Yelimdar \\
\hline 7 & Rhodotorula aurantiaca B & 86 & 0.588 & 4.86 & Identified & Hulet eju enese, Debre Gubae Kebele \\
\hline 8 & Phichia norvegensis & 82 & 0.52 & 5.61 & Identified & Hulet eju enese, Debre Gubae Kebele \\
\hline 9 & Cryptococcus albidus var diffluens & - & 0.558 & 7.81 & Identified & Hulet eju enese, Debre Gubae Kebele \\
\hline 10 & Yeast isolate GTRWSI 8 & - & - & - & No species ID & Hulet eju enese, Debre Gubae Kebele \\
\hline II & Yeast isolate GTS9B & - & - & - & No species ID & Hulet eju enese, Debre Gubae Kebele \\
\hline 12 & Yeast isolate GTS7C & - & - & - & No species ID & Hulet eju enese, Debre Gubae Kebele \\
\hline
\end{tabular}

Table 2 Biolog micro station yeast identification result 


\section{Phosphate solubilization test}

A total of 12 yeast species were evaluated for their phosphate solubilization efficiency on Pikovskaya's agar selective media. Among those identified by micro station, nine yeast species and 3yeast isolates with no species ID were positive for phosphate solubilization (Table 3). Their phosphate solubilization index (PSI) ranges from1.2-3.35 within 15days of incubation (Figure 3). Phichia norvegensis andCryptococcus albidus var aerius were superior in phosphate solubilization with great clear zone diameter and small colony diameter 3.35 and 3.2 respectively (Table 3 ).

Table 3 Phosphate solubilization index (PSI)

\begin{tabular}{lllll}
\hline \multirow{2}{*}{ S. no } & Fungus species isolated from teff rhizosphere soil & \multicolumn{3}{l}{ Phosphate solubilization index (PSI) } \\
\cline { 3 - 5 } & & $\mathbf{5}^{\text {th }}$ days & $\mathbf{I 0}^{\text {th }}$ days & $\mathbf{1 5}^{\text {th }}$ days \\
\hline 1 & Phichia norvegensis & 2.51 & 3 & 3.35 \\
2 & Cryptococcus albidus var aerius & 1.32 & 2.51 & 3.2 \\
3 & Candida etchellsii & 1.76 & 2.54 & 2.9 \\
4 & Cryptococcus albidus var albidus & 2.49 & 2.57 & 2.9 \\
5 & Rhodotrula aurantiacaA & 1.16 & 1.8 & 2.4 \\
6 & Rhodotorula aurantiaca B & 1.55 & 2 & 2.24 \\
7 & Cryptococcus luteolus & 1.8 & 1.82 & 2.22 \\
8 & Cryptococcus albidus var diffluens & 1.54 & 1.67 & 1.9 \\
9 & Cryptococcus terreus A & 1.34 & 1.44 & 1.72 \\
10 & Yeast isolat GTRWSI8 & 1.4 & 1.5 & 1.54 \\
11 & Yeast isolat GTS9B & 1.2 & 1.33 & 1.49 \\
12 & Yeast isolate GTS7C & 0.9 & 1.1 & 1.2 \\
\hline
\end{tabular}
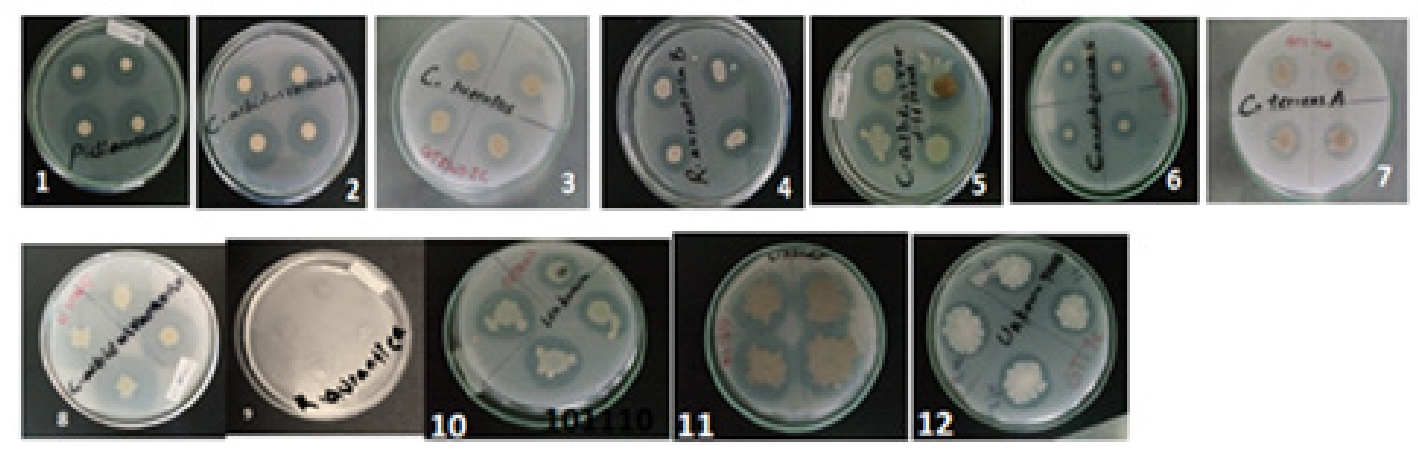

Figure 3 Phosphate solubilizing yeast on Pikovskaya's agar media (I). Phichia norvegensis (2). Cryptococcus albidusvaralbidus (3). Cryptococcus luteollus (4). Rhodotrula aurantiaca B(5). Cryptococcus albidusvardiffluens (6). Candida etchellsii (7). Cryptococus terrusA (8). Cryptococcus albidus var aerius (9). Rhodotrula aurantiacaA (I0). Yeast isolatGTRWSI8 (II). Yeast isolatGTS9B (I2). Yeast isolatGTS7C.

\section{Discussion}

Phosphorus deficiencies are wide spread on soil throughout the world and one of the limiting factors for crop productivity. Phosphorus fertilizers represent major cost for agricultural production. Many bacteria, fungi and a few actinomycetes are potential solubilizers of bound phosphates in soil thus playing an important role making it available to plants in the soluble form. ${ }^{24-27}$ Solubilization of insoluble phosphorus by microorganisms was reported by Pikovskaya. ${ }^{28}$ During the last two decades knowledge on phosphate solubilizing microorganisms increased significantly. ${ }^{22}$ In this study a total of 96 yeast isolates were screened from teff rhizosphere soil collected from Gojam, Ethiopia and 12 yeasts were read by Microstation. Nine yeasts have got full species identification (ID) and 3 with no species ID (Table 2). All yeast species evaluated for their phosphate solubilization ability on Pikovskaya (PVK) selective media. Among all 9 yeast species and 3 isolates were positive for phosphate solubilization. Phichia norvegensis, Cryptococcus albidus var aerius, Candida etchellsii, Cryptococcus albidus var albidus, Rhodotrula
aurantiacaA, Rhodotorula aurantiaca B, Cryptococcus luteolus, Cryptococcus albidus var diffluens, Cryptococcus terreus A (Table 3). Varsha et al., ${ }^{20}$ reported yeast belonging to genus Saccharomyces, Hansenula, Klockera, Rhodotorula and Debaryomyces spp. were phosphate solubilizing yeast. The soil yeasts Candida tropicalis, Geotrichum candidum, Geotrichum capitatum, Rhodotorula minuta and Rhodotorula rubra solubilized insoluble phosphate reported by $\mathrm{Al}$ faith. ${ }^{19}$ Delelegn Woyessa \& Fassil Assefa, ${ }^{29}$ reported bacteria isolated from teff rhizosphere soil from agricultural fields of Alemgena and Bushoftu Ethiopia, isolates teffrhizosphere contains a diverse flora of microorganisms. The genera were Pseudomonas, Chryseomonas, Burkholderia, Bacillus, Brevibacillus, Stenotrophomonas and Aeromonas. These 4 species Bacillus subtilis, Burkholderia cepacia, Pseudomonas fluorescens, Bacillus coagulans were superior phosphate solubilizer bacteria. However many rhizospheric bacteria and fungi isolated from different crop rhizosphere soil, there is little information regarding teff rhizophere yeast and potential phosphate solubilizer yeast. This study will confirm that there are a diverse teff rhizosphere yeast and superior phosphate solubilizer isolated from Gojam teff 
farm land (Table3). The yeast species Rhodotrula aurantiaca $A$ are phosphate solubilizer fungi species discovered in this study are also similar with the work of Yasser et al., ${ }^{30}$ and Isbelia et al. ${ }^{14}$ In this study phosphate solubilization index (PSI) were measured within 5days intervals for 15days of incubation and they measured 1.2 -3.35PSI clear zone diameter over colony diameter ratio (Table 3 ). Narsian et al., ${ }^{31}$ reported yeast belonging to genus Saccharomyces Hansenula, Klockera, Rhodotorula and Debaryomyces exhibited highest SI (1.33-1.50). The study by Yasser et al., ${ }^{30}$ phosphate solubilization index recorded 1.05-1.45. A japonicas $(\mathrm{SI}=1.45)$, A . niger $(\mathrm{SI}=1.12)$, Penicillium expansum (SI=1.20), Penicillium funiculosum $(\mathrm{SI}=1.40)$, Penicillium variable $(\mathrm{SI}=1.13)$, Penicillium purpuragenum $(\mathrm{SI}=1.30)$. In this study the largest solubilization index recorded by Phichia norvegensis(SI. 3.35), Cryptococcus albidus var aerius (SI.3.2), Candida etchellsii (SI.2.9).The smallest solubilization index recorded by Cryptococcus terrus $A$ (PSI, 1.72) (Figure $3 \&$ Table 3). According to De Freitas, good phosphate solubilizers produce halos around their colonies with diameters higher than $1.5 \mathrm{~cm}$. Most efficient phosphate solubilizer on Pikovskaya's agar plates with PSI $=3.29$. Whereas among fungi $P$. canescens sho wed highest solubilizing index Nahas. ${ }^{32}$ Phosphate solubilization index (PSI) values up to 2.4 have been recorded for Aspergillus niger, with values of 3.1 for Penicillium italicum and 3.0 for Paecilomyces lilacinus. ${ }^{33,34}$ Fungal strains isolated from sugarcane and sugar beet rhizosphere showed SI in range of 1.13 to 1.59 Mahamuniet et al. ${ }^{35}$ Alam et al., ${ }^{36}$ reported PSI of the fungal strains isolated from maize rhizosphere that ranged from 1.53 to 1.80 . In this study new phosphate solubilizer yeast Phichia norvegensis, Cryptococcus albidus var aerius identified from teffrizhosphere soil with superior solubilization index (PSI) 3.35 and 3.2 respectively in 15days incubation..$^{37,38}$ Therefore, these strains can be candidated and exploited as bio fertilizers through further evaluation and optimization test to increase agricultural productivity of teff crop. ${ }^{39}$

\section{Conclusion}

Ninety six yeasts were screened from teffrhizosphere soil and morphologically similar isolates were clustered and representative yeast isolates were identified by biolog microstation identification system where equivalent to molecular techniques and the dominant species were Cryptococcus species. Nine yeast species and 3 yeast isolates Phichia norvegensis, Cryptococcus albidus var aerius,Candida etchellsii, Cryptococcus albidus var albidus, Rhodotrula aurantiacaA, Rhodotorula aurantiaca B, Cryptococcus luteolus, Cryptococcus albidus var diffluens, Cryptococcus terreus A, Yeast isolate GTRWS18, GTS9B, GTS7C were positive for phosphate solubilization ability. Phichia norvegensis and Cryptococcus albidus var aerius were superior among the isolated fungi in solubilizing index 3.35 and 3.2respectively and good candidate for biofertilizer after further evaluation on in vitro test, green house and field trials. The rise in the cost of chemical fertilizer, the lack of fertilizer industries in developing countries and the growing environmental issue and biodiversity loss using chemical fertilizer timely important concern using alternative ecofriendly bio fertilizer to increase yield and productivity of teff crop.

Utilization efficiency of crops for phosphate chemical fertilizer is around $30 \%$, the remaining $70 \%$ exist in compound and bound form, Such economic considerations and phosphate existence in compound form necessitate for an alternative less expensive and environmentally friendly bio fertilizer improving yield and quality of teff grain.

\section{Recommendation}

The beneficial effects of plant growth promoting microorganisms
(PGPM) have not been exloited well. In the past some microbial inoculants prepared from Rhizobium for leguminous crops, Azotobacter and Azospirillium for cereal crops and Frankia for tree crops have been used as nitrogen providers in many developed and developing countries. However enormous interest increase in research in recent years in PGPM such as nitrogen fixer, phosphate solubilizer, pathogen suppressor. There is no well-organized microbial inoculant industry for bio fertilizer production especially for phosphate solubilizer and there is no link with researcher working on microbial bio fertilizer in Ethiopia, there for agricultural research institute, microbiologist, soil scientist agronomist, and stockholders in general must work together in depth on structural and functional diversity of PGPM and selecting superior biofertilizer, biopesticide, biostimulant to increase crop yield and prductivity. Further research should be continued with selecting efficient phosphate solubilizer microorganism (PSM) isolates. These may be used for inoculum production and their inoculation effect on the plant growth must be studied in vitro, green house and field trials.

\section{Acknowledgements}

It gives me a great pleasure to acknowledge Dr. Genene Tefera for his unreserved guidance and encouragement and support in providing and facilitating the necessary equipment and extremely greatful to acknowledge Gojam zonal and district agriculture office and leader of all area in the research area who helped me guiding the study site and finally goes to Ethiopian biodiversity institute, microbial directorate for every budget grant to carry out this study and its research team for their un reserved support at laboratory and field work especially Misganaw Wasie, Endeshaw Abatneh, Endegena Aynalem, as part of research group in tireless effort in teffrhizospher soil sample collection. Lastly I acknowledged Woyenshet Lule for her kindly support especially laboratory chemicals facilitation.

\section{Conflict of interest}

The author declares no conflict of interest.

\section{References}

1. Bekabil F, Befekadu B, Rupert S, et al. Strengthening the Teff Value Chain in Ethiopia. Ethiopian Agricultural Transformation Agency, 2011.

2. Beyene D. Diagnosis of phosphorus deficiency in Ethiopian soils. Ethiopia: IAR (Institute of Agriculture); 1982. p. 1-23.

3. Sertsu S, Ali A. Phosphorus sorption characteristics of some Ethiopian soil. Eth J Agric Sci. 1983;34:28-407.

4. Mamo T, Haque I, Kamara CS. Phosphorus status of some Ethiopian high land vertisoles in sub-saharan. Africa J E S. 1988;26:232-252.

5. Saber K L, Nahla A D, ChedlyA. Effect of P on nodule formation and $\mathrm{N}$ fixation in bean. Agron Sustain Dev. 2005;25:389-393.

6. Sharma S, Vijay K, Tripathi RB. Isolation of Phosphate Solubilizing Microorganism (PSMs) from soil. J Microbiololgy Biotechnology Research. 2011;1(2):90-95.

7. Prochnow LI, Fernando J, Quispe S, et al. Effectiveness of phosphate fertilizers of different water solubility's in relation to soil phosphorus adsorption. Sci Agric. 2006;63(4):333-340.

8. Yang M, Ding G, Shi L, et al. Quantitative trait loci for root morphology in response to low phosphorus stress in Brassica napus. Theor Appl Genet. 2010;121(1):181-193.

9. Abate T, Mohamed SMA, Tekalign M, et al. Grain, fodder and residue management. In: Tekalign M, Abiye A, editors. Improved management of Vertisols for sustainable crop-livestock production in the Ethiopian highlands: Synthesis report 1986-92. Ethiopia: Technical Committee of the Joint Vertisol Project; 1993. p. 103-137. 
10. Asfaw H. The effect of phosphate solubilizing fungus on the growth and yield of tef (Eragrostis tef) in phosphorous fixing soils. Eth Sci \& Technol Res Report, 1993. p. 12-14.

11. Khan MS, Zaidi A, Wani PA. Role of phosphate-solubilizing microorganisms in sustainable agriculture - A review. Agron Sustain Dev. 2007;27:29-43

12. Sundara B, Natarajan V, Hari K. Influence of phosphorus solubilizing bacteria on the changes in soil available phosphorus and sugar cane and sugar yields. Field Crops Research. 2002;77:43-49.

13. Kumar A, Choudhary CS, Paswan D, et al. Sustainable way for enhancing Phosphorus efficiency in agricultural soils through phosphate solubilizing microbes. Asian J Soil Sci. 2014;9(2):300-310.

14. Isbelia RL, Bernier RR, Simard P, et al. Characteristics of phosphate solubilization by an isolate of a tropical Penicilliumrugulosum and two UV induced mutants. FEMS Microbiol Ecol. 1999;28(3):291-295.

15. Sparks LD. Advances in Agronomy. USA: Academic Press; 1999. 12 p.

16. Whitelaw MA, Harden JT, Helyar RT. Phosphate solubilization in solution culture by the soil fungus Penicillum radicum. Soil Biol Biochemi. 1999;31:655-665.

17. Didiek G S, Sugiarto Y. Bioactivation of poorly soluble phosphate rocks with a phosphorus-solubilizing fungus. Am J Soil Sci Soc. 2000;64:927932.

18. Helen JBP, Graeme K, Ritz D, et al. Solubilization of calcium phosphate as a consequence of carbon translocation by Rhizoctoniasolani. FEMS Microbiol Ecol. 2002;40(1):65-71.

19. Al-Fatih AM. Phosphate Solubilization in Vitro By Some Soil Yeasts. Qatar Univ Sci J. 2005;25:119-125.

20. Varsha N, Ahmed Abu Samaha SM, Patel HH. Rock phosphate dissolution by specific yeast. Indian J Microbiol. 2010;50(1):57-62.

21. Biolog. YT Microplate instruction or use. 1993.

22. Rao NSS. Phosphate solubilization by soil microorganisms. In: Rao NS, editor. Advanced in Agricultural Microbiology. UK: ButterworthHeinemann; $1982.726 \mathrm{p}$

23. Richardson AE. Prospects of using soil microorganisms to improve the acquisition of phosphorus by plants. Aust J Plant Physiol. 2001;28(9):897-906.

24. Edipremono MA, Moawad PLG. Effect of phosphate solubilizing Pseudmonas putida on the growth of maize and its survival in the rhizosphere. Indonasian J Crop Sci. 1996;11:13-23.

25. Halder AK, Mishra AK, Chakarbarthy PK. Solubilization of inorganic phosphate by Bradyrhizobium. Ind J Exp Biol. 1991;29:28-31.
26. Abdalla MH. Phosphatases and the utilization of organic phosphorus by Rhizobium leguminosarum biovarviceae. Lett Appl Microbiol. 1994;18(5):294-296.

27. Whitelaw M A. Growth promotion of plants inoculated with phosphate solubilizing fungi. Adv Agron. 2000;69:99-151.

28. Goldstein AH. Bacterial solubilization of mineral phosphates: historical perspectives and future prospects. Am J Altern Agric. 1986;1(2):51-57.

29. Pikovskaya RI. Mobilization of phosphorus in soil connection with the vital activity of some microbial species. Micro biologiya. 1948;17:362370 .

30. Delelegn W, Fassil A. Effects of plant growth promoting rhizobaceriaon growth and yield of Tef (Eragrostistef Zucc. Trotter) under Greenhouse Condition. Research J Microbio. 2011;6:343-355.

31. Yasser MM, Ahmad SM, Mousa ON, et al. Solubilization of inorganicphosphate by phosphate solubilizing fungi isolated from Egyptian soils . J Biol Earth Sci. 2014;4(1):83-90.

32. Narsian V, Ahmed Abu Samaha SM, Patel HH. Rock phosphate dissolution by specific Yeast. Indian J Microbiol. 2010;50(1):57-62.

33. Nahas E. Factors determining rock phosphate solubilization by microorganisms isolated from soil. World $J$ Microbiol Biotech. 1996;12(6):567-572.

34. El-Azouni IM. Effect of phosphate solubilizing fungi on growth and nutrient uptake of soybean (Glycinemax L) plants. J Appl Sci Res. 2008;4(6):592-598.

35. Hernández LT, Carrión G, Heredia G. Solubilización in vitro de fosfatos por una cepa de Paecilomyceslilacinus (Thom) Samsom. Agrociencia. 2011;45(8):881-892.

36. Mahamuni SV, Wani PV, Patil AS. Isolation of phosphate solubilizing fungi from rhizosphere of sugarcane and sugar beet using TCP and RP solubilization. Asian J Biochem and Pharmaceutical Research. 2012;2:237-244.

37. Alam S, Khalil S, Ayub $\mathrm{N}$, et al. In vitro solubilization of inorganic phosphate by phosphate solubilizing microorganisms (PSM) from maize rhizosphere. Int J Agri and Biol. 2002;4(4):454-458.

38. Ogoshi A, Kobayashi K, Homma Y, et al. Japan: Nakanishi Sapporo; p. 209-2011.

39. Food and Agricultural Organization. Master Land Use Plan, Ethiopia Range/Livestock Consultancy. Report prepared for the Government of the People's Democratic Republic of Ethiopia. Italy: Food and Agricultural Organization (FAO); 1987. 116 p. 